\title{
An investigation of flux characteristic in direct torque control using sector rotation strategy
}

\author{
Siti Azura Ahmad Tarusan', Auzani Jidin², Mohd Luqman M. Jamil ${ }^{3}$, Kasrul Abdul Karim ${ }^{4}$ \\ ${ }^{1-4}$ Faculty of Electrical Engineering, Universiti Teknikal Malaysia Melaka (UTeM), Malaysia \\ ${ }^{1,2}$ Power Electronics and Drives Research Group, CeRIA, UTeM, Malaysia \\ ${ }^{3,4}$ Electrical Machine Design, Power Electronics and Drives Research Group, CeRIA, UTeM, Malaysia
}

\begin{tabular}{l} 
Article Info \\
\hline Article history: \\
Received May 11, 2021 \\
Revised Sep 8, 2021 \\
Accepted Sep 15, 2021 \\
\hline
\end{tabular}

Keywords:

Direct torque control

Sector rotation strategy

Stator flux

Various speed

\begin{abstract}
Stator flux fails to regulate at low operating speed condition is a common drawback for the conventional direct torque control (DTC). It is due to the inevitable of zero-voltage vector demagnetization that interrupts the controlling of stator flux in DTC. Hence, a fixed sector rotation strategy is one of the solutions to rectify the raised issue. The strategy is based on the decreasing stator flux droop, which is an easy technique to change the sector of flux locus at a specific angle. However, this strategy only focuses at low operating speed. Thus, the stator flux droop effect at the various speed needs to be analysed. In this paper, an investigation is conducted by using simulation (MATLAB/Simulink) and experimental setup (dSPACE board) where a good agreement has been achieved between the predicted and measured results. The analysis taking into account between the conventional method (without strategy) and the proposed method (with strategy). In conclusion, the influence of stator flux droop is inversely proportional to the operating speed.
\end{abstract}

This is an open access article under the CC BY-SA license.

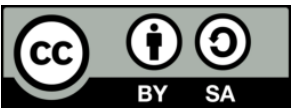

\section{Corresponding Author:}

Siti Azura Ahmad Tarusan

Faculty of Electrical Engineering

Universiti Teknikal Malaysia Melaka

76100 Durian Tunggal, Melaka, Malaysia

Email: sitiazura@utem.edu.my

\section{INTRODUCTION}

In the application of $\mathrm{AC}$ drives, the potential of direct torque control (DTC) to give quick control is gaining a lot of attention. Furthermore, rather than field oriented control (FOC), which was the first implementation in electrical control, it became recognised for its simple features in control strategy [1]. The DTC control technique is produced by selecting a voltage vector that allows the torque and flux to remain within the hysteresis band [2]-[4]. The hysteresis-based DTC, on the other hand, has a number of problems, including variable switching frequency, high torque and flux ripples, and worsening of stator flux regulation at low speeds [5]-[10].

The great development of DTC is by using space vector modulation, commonly called as DTCSVM. This control strategy employs the synthesized principal in space vector modulator for sampling the reference stator voltage [11]-[13]. Although the constant switching frequency and the minimal torque and flux ripple are achievable, but it increases the burden in-computational of digital signal processing system to implement SVM. Alternatively, a duty cycle-based strategy is introduced to solve the DTC problem by controlling the torque slope profile through the adjustment of voltage vector within their stipulated [14]-[17]. However, the complex calculation is required to achieve the minimum torque ripple. Other effort is proposed 
by using multilevel inverter as [18]-[22] but it suffers to a large and complex algorithm in the look-up table of DTC. Stator flux regulation in the DTC is degraded at low operating speed It is due to the unavoidable demagnetization caused by the zero-voltage vector. As for the reason, the droop appears hence disturbing the regulation of stator flux [23]. Several solutions for handling the stator flux problem are suggested in [18], [24]-[27]. The simple strategy in [25] has described the stator flux is improved by using fixed sector rotation strategy but only focuses at low-operating speed. Thus, this strategy is extended into this paper to analyse the effect of stator flux performance in the various speed conditions. The investigation is conducted via MATLAB/Simulink package and an experimental setup (an implementation of dSPACE DS1104 controller board). Two conditions, a conventional method (without strategy) and a proposed method (with strategy) in the DTC scheme are included for a comparison purpose.

\section{PROPOSED STRUCTURE OF BASIC DTC}

The basic drive control of DTC by Takahashi [4] is constructed with the addition of shifted angle labeled as modified sector shown in Figure 1. The construction is built by using control element (torque and flux hysteresis comparators), drive element (lookup table and two-level inverter) as well as feedback element (voltage and current calculation, sector detection and also torque and flux estimators). It is modified by adding the angle shifted $\Delta \vartheta$, in the sector detection to perform the fixed sector rotation strategy as proposed in [24]. The AC machine in DTC is driven by using two-level inverter that produces eight voltage vectors as illustrated in the mapping voltage vector in Figure 2 (a). The mapping vector as the switching state of inverter is consisted of two zero voltage vectors (V0 and V7) and six active voltage vectors (V1-V6) in the hexagonal diagram. The voltage vectors are adapted into six sectors which divided equally by $60^{\circ}$ on the stator flux d-q plane as illustrated in Figure 2(b). This sector is applied to perform the circular locus of stator flux trajectory by using the two possible voltage vectors in order to either increase or decrease the stator flux, $\varphi_{s}$. The two possible voltage vectors that applied as a tangential vector may produce the good torque response in the DTC drive system [4].

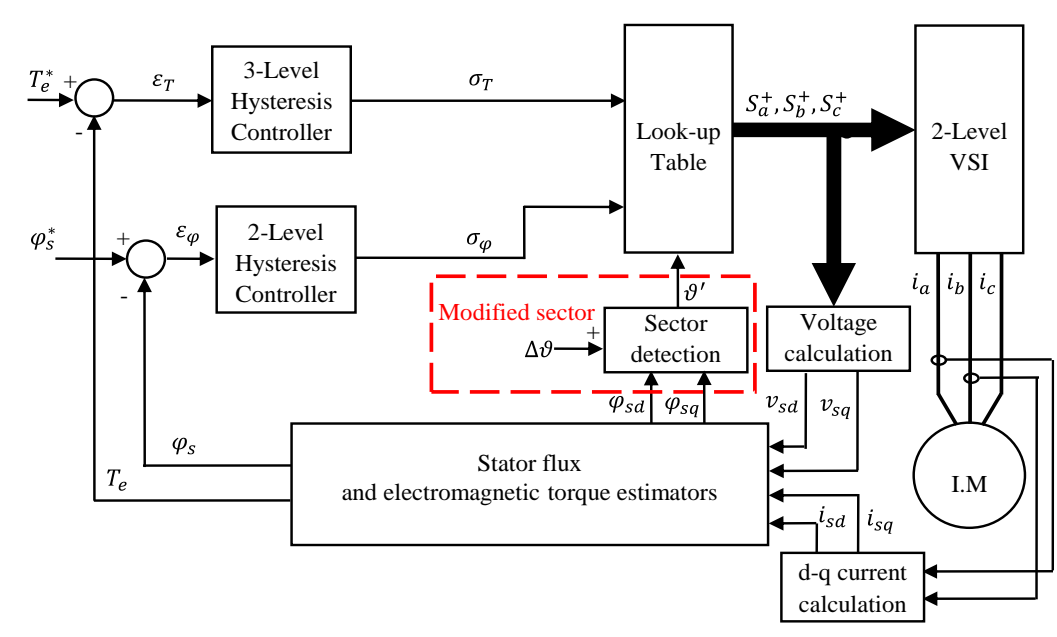

Figure 1. The basic DTC drive system with the addition of shifted angle labeled as the modified sector [24]

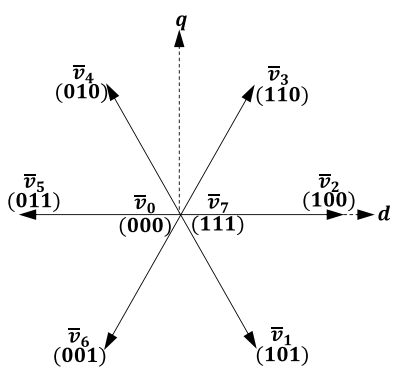

(a)

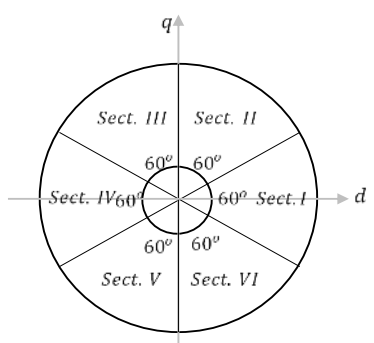

(b)

Figure 2. The diagram of, (a) mapping vector of two-level inverter circuit and (b) d-q plane of stator flux 


\section{STATOR FLUX OPERATION}

In DTC, the variation of stator flux, $\varphi_{s}$ is controlled by using two possible voltages as defined in mapping vector. As shown in Figure 3 (a), such in sector $V I$, the active voltage vector $\bar{v}_{2}$ and $\bar{v}_{3}$ are used to increase or decrease the flux. After changing into sector, $I$, the active voltage vector alternates by using $\bar{v}_{3}$ to increase flux while $\bar{v}_{4}$ to decrease the flux. It will produce the consistent variation of stator flux applied by the same magnitude and angle of voltage vector and continuously applicable into the other sector. This case is significant by ignoring the stator resistance as the stator flux is fully controlled by the voltage vector.

However, the case as mentioned previously is irrelevant at low operating speed. Normally, the operation of torque (increase or decrease) is controlled by using active voltage vectors and also zero-voltage vector [25]. Zero-voltage vector is applied whenever the torque is at a constant condition. When the motor operates at low-speed, the demagnetization occurs as the stator flux movement is hold by decreasing the torque using zero-voltage vector [24]. The expression of stator flux change using zero voltage vector is stated in equation (1). As highlighted in (1), the stator flux is reduced by the expression of ohmic voltage drop produced by stator resistance. The continuous reduction of stator flux beyond the lower band flux hysteresis may cause the flux droop [25].

In order to overcome the problem, the fixed sector rotation strategy proposed in [24] is used to reduce the stator flux droop at low operating speed. It is implemented by shifting the sector of stator flux, $\theta_{n}$ by adding the shifted angle, $\Delta \vartheta$ to the original angle at sector detection as stated in (2) shown in Figure 4. The arrangement in the lookup table is maintained to select the voltage vector for the switching states of inverter. Consequently, the better tangential voltage vector is achieved to reduce the stator flux droop on the particular sector. In this paper, the analysis is conducted by studying the effect of shifted angle improving stator flux droop, $\Delta \varphi_{s}$ to the variation of speed, $\omega_{m}$.

$$
\begin{gathered}
\Delta \overline{\varphi_{s}}=-R_{s} \overline{l_{s}} \Delta t \\
\theta_{n}{ }^{\prime}=\theta_{n}+\Delta \vartheta
\end{gathered}
$$

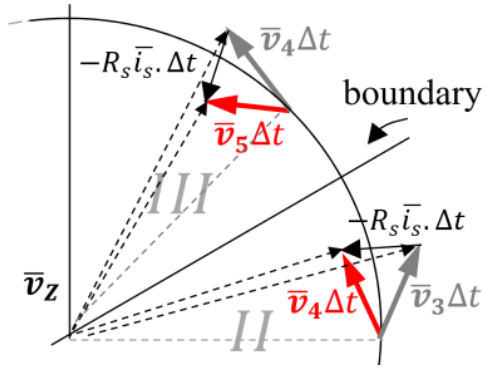

(a)

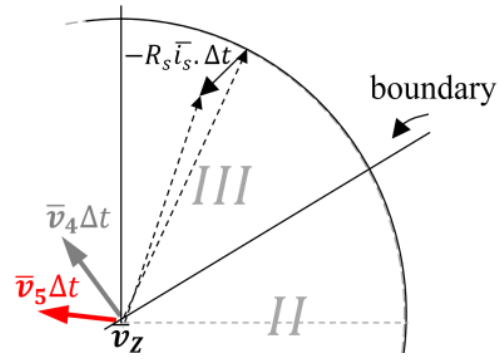

(b)

Figure 3. The operation of stator flux in; (a) ideal case and (b) demagnetization by zero voltage vector [24]

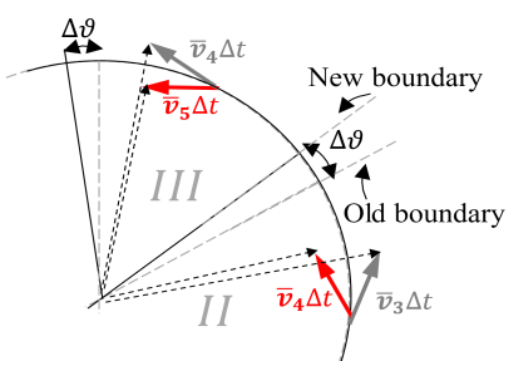

Figure 4. The shifted sector by using fixed sector rotation strategy [25]

\section{RESULTS AND DISCUSSION}

In order to analyse the effect of stator flux in DTC, the simulation and experiment test are conducted with the employment of induction motor parameter as listed in Table 1. It is also realized by the comparison performance between the conventional method with the proposed method. The simulation is implemented by 
using MATLAB/Simulink package. Meanwhile, the experiment setup is conducted by using a $1.1 \mathrm{~kW}$ squirrel-cage induction motor as it is driven by the two-level inverter circuit with the supply voltage of $100 \mathrm{~V}$. In addition, the DTC scheme is realized by using the controller board of dSPACE DS1104 with the sampling time of $50 \mu$. The experiment setup for implementing the DTC scheme is illustrated in Figure 5.

Table 1. The list parameter of induction machine

\begin{tabular}{lclc}
\hline Induction Machine & & & \\
\hline Rated power, $P$ & $1.1 \mathrm{~kW}$ & Frequency, $f$ & $50 \mathrm{~Hz}$ \\
Rated speed, $\omega_{m \text { (rated })}$ & $2800 \mathrm{rpm}$ & Stator self-inductance, $L_{s}$ & $0.47979 \mathrm{mH}$ \\
Rated torque, $T_{e(\text { rated })}$ & $4 \mathrm{Nm}$ & Rotor self-inductance, $L_{r}$ & $0.47979 \mathrm{mH}$ \\
Rated flux, $\varphi_{s(\text { rated })}$ & $0.8452 \mathrm{~Wb}$ & Mutual inductance, $L_{m}$ & $0.4634 \mathrm{mH}$ \\
Stator resistance, $R_{s}$ & $6.1 \Omega$ & Combined Inertia, $J$ & $0.0565 \mathrm{~kg} . \mathrm{m}^{2}$ \\
Rotor resistance, $R_{r}$ & $6.2293 \Omega$ & Numbers of pole pairs & 1 \\
\hline
\end{tabular}

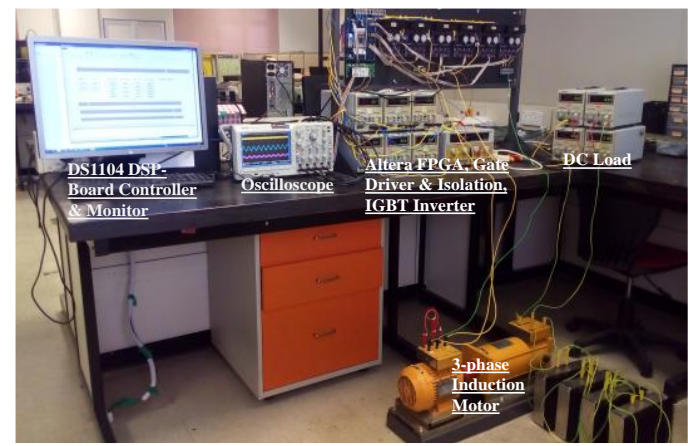

Figure 5. The experiment setup of DTC drive system

In a real implementation, the test is carried out by setting the reference torque and stator flux at 1.5 $\mathrm{Nm}$ and $0.8452 \mathrm{~Wb}$ respectively. The analysis only emphasizes on the stator flux performance while the torque response has kept regulated on its reference. Based on the motor specification, the stator flux performs $0.8452 \mathrm{~Wb}$ which is tiny and difficult to capture. Hence, the value of stator flux is enlarged into $8.452 \mathrm{~Wb}$ by multiplying it with 10 . Then, it is subtracted with 8 to produce $0.452 \mathrm{~Wb}$. As a result, the stator flux waveform enables to be observed within the range of $0.452 \mathrm{~Wb}$ which is identical to the real value of stator flux, $0.0452 \mathrm{~Wb}$. Thus, in the experimental setup, the range of stator flux is assumed to be adjusted at 0.02 $\mathrm{Wb} / \mathrm{div}$ (identical to the real value).

The stator flux droop is tested and compared on various low speeds, specifically from $500 \mathrm{rpm}$ to $150 \mathrm{rpm}$ with a uniform interval of $50 \mathrm{rpm}$. The analysis is carried out using a simulation and an experimental setup, which both of them yield result similar performance. Figure 6 shows the stator flux droop performance at operating speed of $500 \mathrm{rpm}$. In the conventional DTC scheme, the stator flux has resulted the droop of $0.0152 \mathrm{~Wb}$. By using the proposed method of fixed sector rotation strategy, the angle of sector has been shifted into $10^{\circ}$ to reduce the droop. This shifted angle is represented by the shifted sector performed in the proposed method. As the speed reduces into $450 \mathrm{rpm}$ (shown in Figure 7), it is noticed that the droop of stator flux has reached $0.0172 \mathrm{~Wb}$. In order to improve the droop, the sector is changed by modifying the angle into $11^{\circ}$ in the proposed method.

Further, the motor load is adjusted at the middle range to allow the motor operates at medium operating speed of $300 \mathrm{rpm}$ as presented in Figure 8. From the figure, the stator flux droop at $0.0262 \mathrm{~Wb}$ in the conventional method is reduced by shifting the angle of sector into $14^{\circ}$ in the proposed method. Later, by increasing the motor load at high condition (Figure 9), the stator flux droop in the conventional method has reached $0.0372 \mathrm{~Wb}$ at low operating speed. Thus, the shifted angle of $15^{\circ}$ is suggested in the proposed method to minimize the stator flux droop. The stator flux droop getting worse when the motor is loaded gradually. At a very low operating speed as presented in Figure 10, the modified angle of $16^{\circ}$ is used to shift the sector to minimize the $0.0472 \mathrm{~Wb}$ droop of stator flux produced in the conventional method. The observation is tabulated in Table 2, and plotted into the graph of speed (rpm) againts shifted angle as shown in Figure 11. From the graph, the slope is negative and and complies the equation (3) and comfirms the shifted angle, $\Delta \vartheta$ is inversely proportional to the speed, $\omega_{m}$ as in (4). This phenomenon inherently results a similar relationship between the stator flux droop, $\Delta \varphi_{s}$ and the speed, $\omega_{m}$ at a constant torque as stated in (5). 
$y=-m x+C$

$\Delta \vartheta \propto \frac{1}{\omega_{m}}$

$\Delta \varphi_{s} \propto \frac{1}{\omega_{m}}$

Table 2. The result of the stator flux droop at various operating speed

\begin{tabular}{ccc}
\hline Speed $(\mathrm{rpm})$ & Flux droop $(\mathrm{Wb})$ & Shifted angle $\left({ }^{\circ}\right)$ \\
\hline 500 & 0.0152 & 10 \\
450 & 0.0172 & 11 \\
300 & 0.0262 & 14 \\
200 & 0.0372 & 15 \\
150 & 0.0472 & 16
\end{tabular}

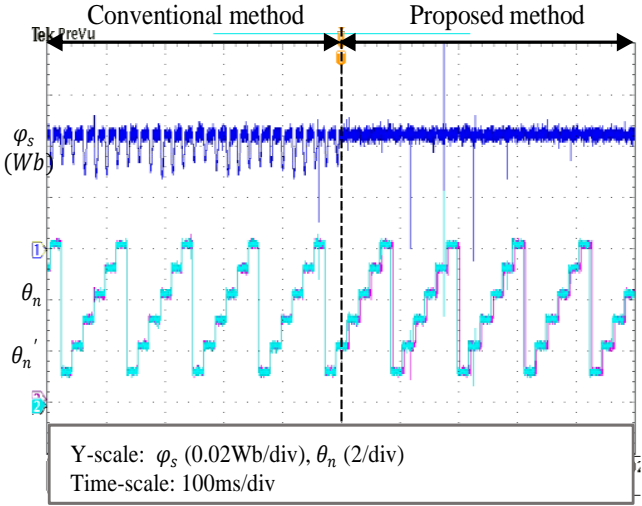

(a)

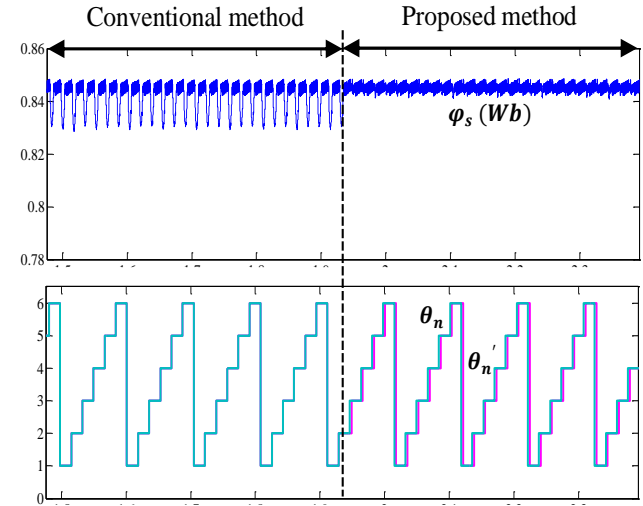

(b)

Figure 6. Stator flux, $\varphi_{s}$ (upper), sector, $\theta_{n}$ and shifted sector, $\theta_{n}{ }^{\prime}$ (lower) through the, (a) experimental and (b) simulation result at $500 \mathrm{rpm}$

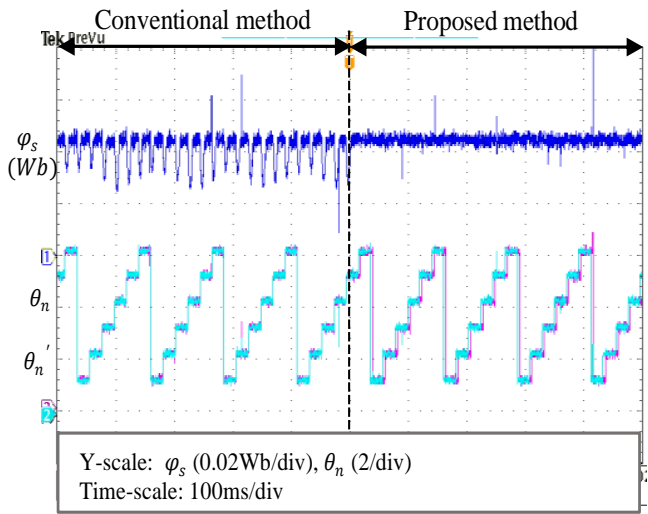

(a)

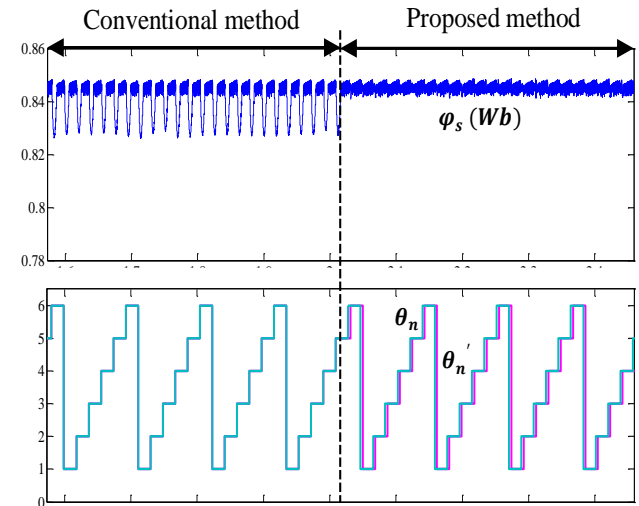

(b)

Figure 7. Stator flux (upper), $\varphi_{s}$ sector, $\theta_{n}$ and shifted sector, $\theta_{n}{ }^{\prime}$ (lower) through the, (a) experimental and (b) simulation result at $450 \mathrm{rpm}$ 


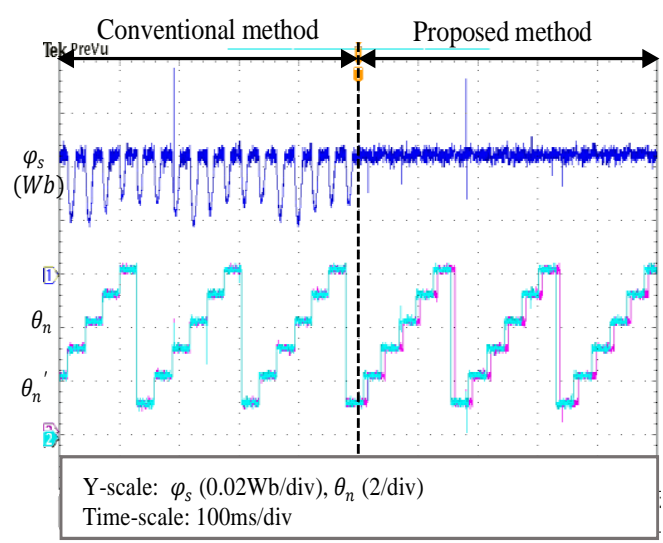

(a)

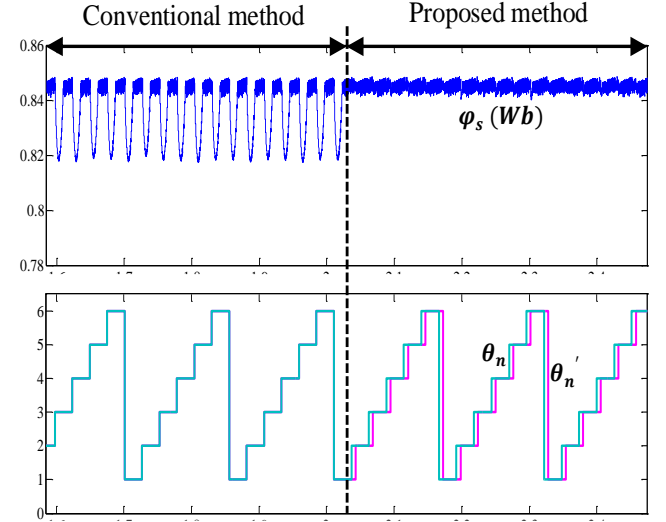

(b)

Figure 8. Stator flux (upper), $\varphi_{s}$ sector, $\theta_{n}$ and shifted sector, $\theta_{n}{ }^{\prime}$ (lower) through the, (a) experimental and (b) simulation result at $300 \mathrm{rpm}$

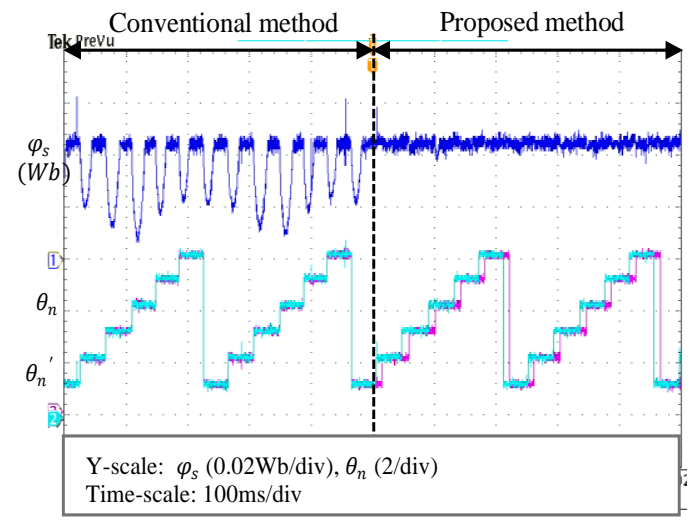

(a)

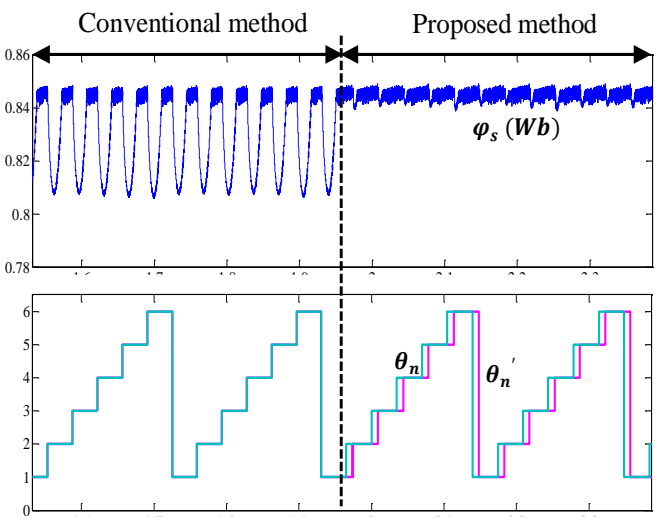

(b)

Figure 9. Stator flux (upper), $\varphi_{s}$ sector, $\theta_{n}$ and shifted sector, $\theta_{n}{ }^{\prime}$ (lower) through the; (a) experimental and (b) simulation result at $200 \mathrm{rpm}$

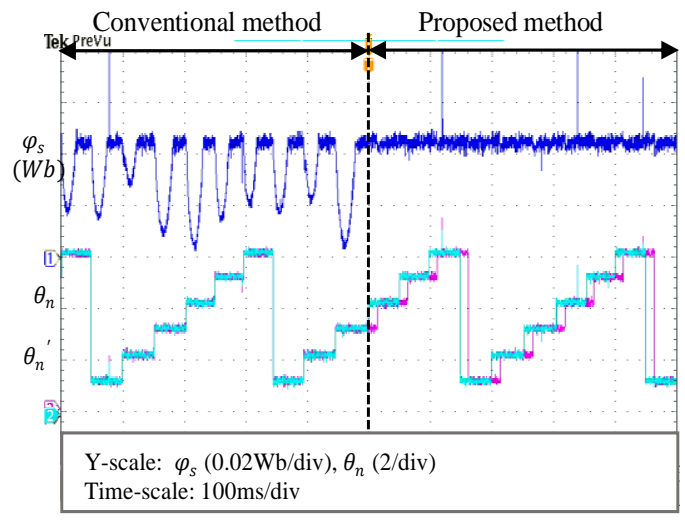

(a)

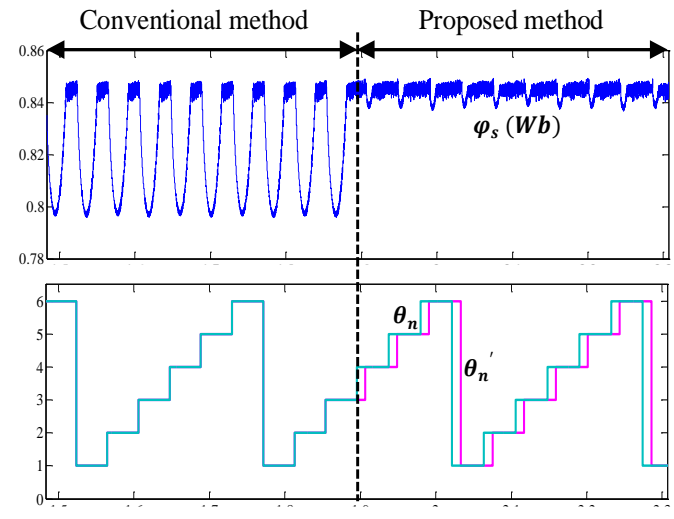

(b)

Figure 10. Stator flux (upper), $\varphi_{s}$ sector, $\theta_{n}$ and shifted sector, $\theta_{n}{ }^{\prime}$ (lower) through the, (a) experimental and (b) simulation result at $150 \mathrm{rpm}$ 


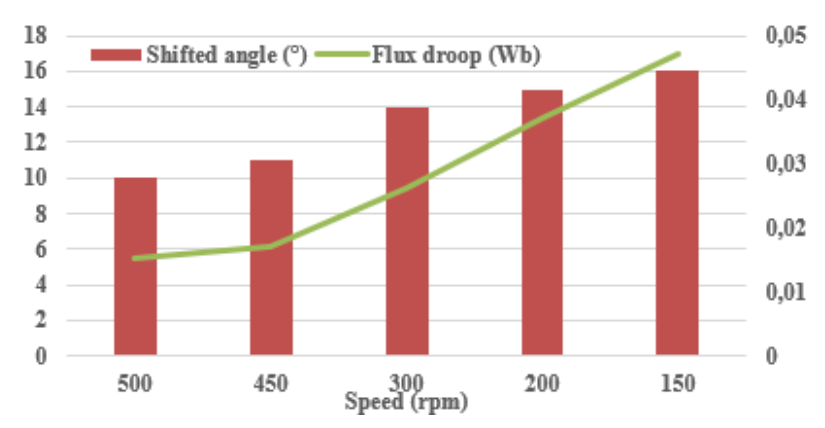

Figure 11. The graph of shifted angle against the speed at torque of $1.5 \mathrm{Nm}$

\section{CONCLUSION}

The aim of this paper to investigate an influence stator flux on the DTC scheme by using a fixed sector rotation strategy as proposed in the previous studies is achieved. This is done by comparing the conventional method without a fixed sector rotation strategy with a proposed method which sector rotation strategy is fixed. A good agreement of results between the simulation and experimental setup is achieved where the proposed method has effectively reduced the stator flux droop than the conventional method. In the conclusion, the stator flux droop is inversely proportional to the operating speed as shown by the variation of speeds.

\section{ACKNOWLEDGEMENTS}

The authors gratefully acknowledge the financial support provided by the Ministry of Higher Education, Malaysia, (MOHE) and Universiti Teknikal Malaysia Melaka (UTeM).

\section{REFERENCES}

[1] U. R. Chinthakunta, K. K. Prabhakar, A. K. Singh, and P. Kumar, "Direct torque control induction motor drive performance evaluation based on torque error status selection methods," IET Electrical Systems Transportation, vol. 9, no. 3, pp. 113-127, 2019, doi: 10.1049/iet-est.2018.5005.

[2] D. Casadei, G. Grandi, G. Serra and A. Tani, "Effects of flux and torque hysteresis band amplitude in direct torque control of induction machines," Proceedings of IECON'94-20th Annual Conference of IEEE Industrial Electronics, 1994, pp. 299-304 vol.1, doi: 10.1109/IECON.1994.397792.

[3] S. Allirani, N. S. Lakshmi, and H. Vidhya, "Performance analysis on direct torque controlled induction motor drive with varying hysteresis controller bandwidth," International Journal of Power Electronics and Drive System IJPEDS, vol. 11, pp. 1165-1174, 2020, doi: 10.11591/ijpeds.v11.i3.pp1165-1174.

[4] I. Takahashi and T. Noguchi, "A New Quick-Response and High-Efficiency Control Strategy of an Induction Motor," IEEE Transactions on Industry Applications, vol. IA-22, no. 5, pp. 820-827, 1986, doi: 10.1109/TIA.1986.4504799.

[5] R. H. Kumar, A. Iqbal, and N. C. Lenin, "Review of recent advancements of direct torque control in induction motor drives-a decade of progress," IET Power Electronics, vol. 11, pp. 1-15, 2018, doi: 10.1049/ietpel.2017.0252.

[6] M. Ouhrouche, R. Errouissi, A. M. Trzynadlowski, K. A. Tehrani and A. Benzaioua, "A Novel Predictive Direct Torque Controller for Induction Motor Drives," IEEE Transactions on Industrial Electronics, vol. 63, no. 8, pp. 5221-5230, Aug. 2016, doi: 10.1109/TIE.2016.2558140.

[7] M. K. Rahim, A. Jidin, and T. Sutikno, "Enhanced torque control and reduced switching frequency in direct torque control utilizing optimal switching strategy for dual-inverter supplied drive," International Journal of Power Electronics and Drive System IJPEDS, vol. 7, no. 2, pp. 328-339, 2016.

[8] N. R. N. Idris and A. H. M. Yatim, "Direct torque control of induction machines with constant switching frequency and reduced torque ripple," IEEE Trans. Ind. Elect., vol. 51, no. 4, pp. 758-767, 2004, doi: 10.1109/TIE.2004.831718.

[9] S. A. A. Tarusan, A. Jidin, M. L. M. Jamil, K. A. Karim, and T. Sutikno, "A review of direct torque control development in various multilevel inverter applications," International Journal of Power Electronics and Drive System, vol. 11, no. 3, pp. 1675-1688, 2020, doi: 10.11591/ijpeds.v11.i3.pp1675-1688.

[10] A. Jidin, K. A. Karim, K. Rahim, L. Raj, Logan Victor, S. Ramahlingam, and T. Sutikno, "A Review on Constant Switching Frequency Techniques for Direct Torque Control of Induction Motor," International Journal of Power Electronics and Drive System, vol. 7, pp. 364-372, 2017, doi: 10.11591/ijeecs.v7.i2.pp364-372.

[11] M. A. Usta, H. I. Okumus, and H. Kahveci, "A simplified three-level SVM-DTC induction motor drive with speed and stator resistance estimation based on extended Kalman filter," Electrical Engineering, vol. 99, pp. 707-720, 2017, 10.11591/ijeecs.v7.i2.pp364-372.

[12] A. Kumar, B. G. Fernandes and K. Chatterjee, "Direct torque control of open-end winding induction motor drive 
using the concept of imaginary switching times for marine propulsion systems," 31st Annual Conference of IEEE Industrial Electronics Society, IECON, 2005, pp. 6, doi: 10.1109/IECON.2005.1569127.

[13] M. Jafari, K. Abbaszadeh, and M. Mohammadian, "A novel DTC-SVM approach for two parallel-connected induction motors fed by matrix converter," Turkish Journal of Electrical Engineering \& Computer Sciences, vol. 26, pp. 1599-1611, 2018, doi: 10.3906/elk-1611-168.

[14] T. Yuan, D. Wang, Y. Li, S. Tan, and S. Zhou, "Duty ratio modulation method to minimise torque and flux linkage ripples for IPMSM DTC system,” Electronic Letters, vol. 53, no. 17, pp. 1188-1190, 2017.

[15] D. Mohan, X. Zhang and G. H. B. Foo, "A Simple Duty Cycle Control Strategy to Reduce Torque Ripples and Improve Low-Speed Performance of a Three-Level Inverter Fed DTC IPMSM Drive," IEEE Transactions on Industrial Electronics, vol. 64, no. 4, pp. 2709-2721, 2017, doi: 10.1109/TIE.2016.2636202.

[16] W. Chen, C.-L. Xia, Y.-Y. Zhao, Y. Yan, and Z.-Q. Zhou, "Torque Ripple Reduction in Three-Level Inverter-Fed Permanent Magnet Synchronous Motor Drives by Duty-Cycle Direct Torque Control Using an Evaluation Table," Journal of Power Electronics, vol. 17, pp. 368-379, 2017, doi: 10.6113/JPE.2017.17.2.368.

[17] Z. Zhang and X. Liu, "A Duty Ratio Control Strategy to Reduce Both Torque and Flux Ripples of DTC for Permanent Magnet Synchronous Machines," IEEE Access, vol. 7, pp. 11820-11828, 2019, doi: 10.1109/ACCESS.2019.2892121.

[18] S. A. A. Tarusan, A. Jidin, and M. L. M. Jamil, "The simulation analysis of torque ripple reduction by using optimal voltage vector in DTC fed by five-level CHB inverter," Indonesian Journal of Electrical Engineering and Computer Science, vol. 20, no. 3, pp. 1665-1676, 2020, doi: 10.11591/ijeecs.v20.i3.pp1665-1676.

[19] D. Mohan, X. Zhang and G. H. Beng Foo, "Generalized DTC Strategy for Multilevel Inverter Fed IPMSMs With Constant Inverter Switching Frequency and Reduced Torque Ripples," IEEE Transactions on Energy Conversion, vol. 32, no. 3, pp. 1031-1041, Sept. 2017, doi: 10.1109/TEC.2017.2681653.

[20] S. A. L. Ramahlingam, A. Bin Jidin, T. Sutikno, and L. L. Raj, "Improvise 3-level DTC of induction machine using constant switching frequency method by utilizing multiband carrier," International Journal of Power Electronics and Drive System IJPEDS, vol. 7, no. 3, pp. 638-647, 2016, doi: 10.11591/ijpeds.v7.i3.pp638-647.

[21] S. Priya, A. Suresh, and M. R. Rashmi, "GCMT-249 Investigation and Performance Analysis of Direct Torque Control of 3phase Induction Motor using 7 Level Neutral Point Clamped Multilevel Inverter," Indian Journal of Science and Technology, vol. 9, no. 24, pp. 1-7, 2016, doi: 10.17485/ijst/2016/v9i24/95173.

[22] S. Suresh and P. P. Rajeevan, "Virtual Space Vector-Based Direct Torque Control Schemes for Induction Motor Drives," IEEE Transactions on Industry Applications, vol. 56, no. 3, pp. 2719-2728, May-June 2020, doi: 10.1109/TIA.2020.2978447.

[23] N. R. N. Idris and A. H. M. Yatim, "An improved stator flux estimation in steady-state operation for direct torque control of induction machines," IEE Proceedings - Electric Power Applications, vol. 38, no. 1, pp. 110-116, 2002, doi: 10.1109/28.980364.

[24] L. Kyo-Beum, S. Joong-Ho, I. Choy, and Y. Ji-Yoon, "Improvement of Low-Speed Operation Performance," IEEE Trans. Ind. Electron., vol. 48, pp. 1006-1014, 2001.

[25] W. S. H. Wong and D. Holliday, "Minimisation of flux droop in direct torque controlled induction motor drives," IEE Proceedings-Electric Power Applications, vol. 151, no. 6, pp. 694-703, 2004, doi: 10.1049/ip-epa:20040681.

[26] B. Singh, S. Jain, and S. Dwivedi, "Torque ripple reduction technique with improved flux response for a direct torque control induction motor drive," IET Power Electronics, vol. 6, pp. 326-342, 2013: doi: 10.1049/ietpel.2012.0121.

[27] I. M. Alsofyani and N. R. N. Idris, "Simple Flux Regulation for Improving State Estimation at Very Low and Zero Speed of a Speed Sensorless Direct Torque Control of an Induction Motor," IEEE Transactions on Power Electronics, vol. 31, no. 4, pp. 3027-3035, April 2016, doi: 10.1109/TPEL.2015.2447731.

\section{BIOGRAPHIES OF AUTHORS}

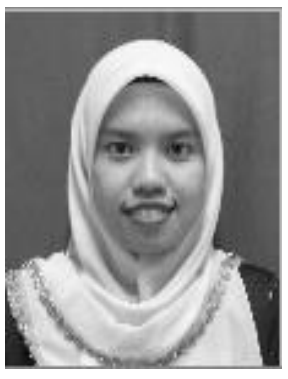

S. A. A. Tarusan received the B.Eng. degrees from Universiti Teknologi Malaysia, Johor Bahru, Malaysia, in 2008 and M.Eng. degrees from Universiti Malaya, Malaysia, in 2012. She is currently pursuing PhD under Power Electronics and Drives Research Group (PEDG) in the Faculty of Electrical Engineering, Universiti Teknikal Malaysia Melaka, Melaka, Malaysia. Her research interests include power electronics and motor drive systems. 


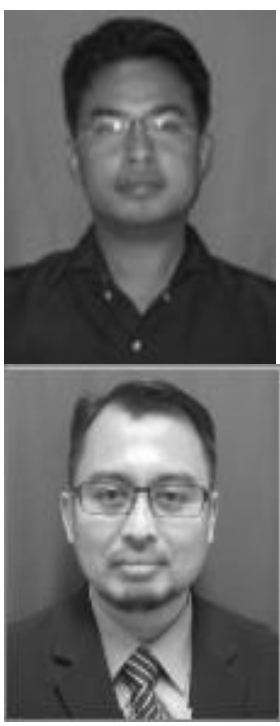

A. Jidin received the B.Eng. degrees, M.Eng. degrees and Ph.D. degree in power electronics and drives from Universiti Teknologi Malaysia, Johor Bahru, Malaysia, in 2002, 2004 and 2011, respectively. He is currently an academician in Faculty of Electrical Engineering, Universiti Teknikal Malaysia Melaka, Melaka, Malaysia. He is also an active researcher in Power Electronics and Drives Research Group (PEDG) that established under the same faculty. His research interests include power electronics, motor drive systems, fieldprogrammable gate array, and DSP applications.

M. L. M. Jamil received B. Eng. degree from the Universiti Teknologi MARA, Shah Alam, Malaysia, in 2000, M.Sc. degree from University of Newcastle upon Tyne, U.K., in 2003, and Ph.D. degree from The University of Sheffield, Sheffield, U.K., in 2011, all in electrical engineering. He is currently an academician in Faculty of Electrical Engineering, University Teknikal Malaysia Melaka, Melaka, Malaysia. He is also an active researcher in Power Electronics and Drives Research Group (PEDG) that established under the same faculty. His research interests include the design, control and analysis of permanent-magnet machines.

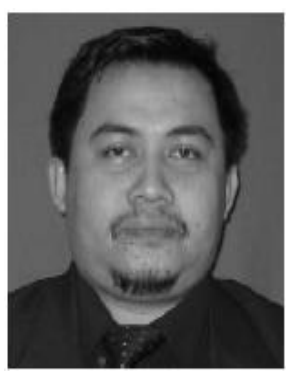

K. A. Karim received the M.Sc. from University of Bradford and Ph.D. degrees from the University of Nottingham, UK, in 2003 and 2011, respectively He is currently an academician in Faculty of Electrical Engineering, University Teknikal Malaysia Melaka, Melaka, Malaysia. $\mathrm{He}$ is also an active researcher in Power Electronics and Drives Research Group (PEDG) that established under the same faculty. His research interests include electrical machine design, power electronics, and electric vehicle. 